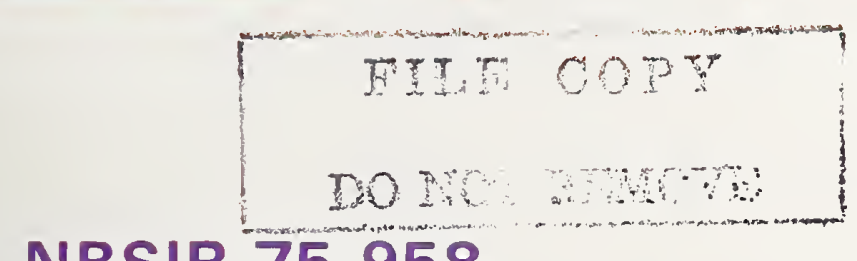

$107.100 \times 11$

NBSIR 75-958

\title{
Simulated Precipitation Reference Materials
}

J. K. Taylor, E. R. Deardorff, R. A. Durst, E. J. Maienthal,

T. C. Rains, and E. P. Scheide

National Bureau of Standards

Department of Commerce

Washington, D. C. 20234

October 1975

Final Report

Prepared for

The Environmental Protection Agency

Office of Research and Development

Research Triangle Park, North Carolina 27711 

NBSIR 75-958

SIMULATED PRECIPITATION REFERENCE MATERIALS

J. K. Taylor, E. R. Deardorff, R. A. Durst, E. J. Maienthal, T. C. Rains, and E. P. Scheide

National Bureau of Standards

Department of Commerce

Washington, D. C. 20234

October 1975

Final Report

Prepared for

The Environmental Protection Agency

Office of Research and Development

Research Triangle Park, North Carolina 27711

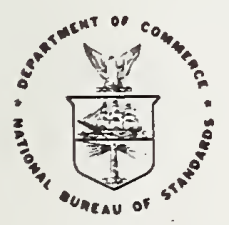

U.S. DEPARTMENT OF COMMERCE, Rogers C.B. Morton, Secretary James A. Baker, III, Under Secretary

Dr. Betsy Ancker-Johnson, Assistant Secretary for Science arid Technology

NATIONAL BUREAU OF STANDARDS, Ernest Ambler, Acting Director 
$\underline{\text { Page }}$

1. INTRODUCTION . . . . . . . . . . . . . . . 1

2. EXPERIMENTAL DETAILS . . . . . . . . . . . 2

2.1 General Considerations. . . . . . . . . . 2

2.2 Preparation of Reference Materials. . . . . 3

2.3 Ampouling . . . . . . . . . . . . . 3

2.4 Numbering Sequence. . . . . . . . . . . . 4

2.5 Analysis of Bulk Solutions. . . . . . . . 4

2.6 Analysis of Ampoules. . . . . . . . . . 4

2.6.1 pH Measurements. . . . . . . . . 5

2.6.2 Conductivity Measurements. . . . . . 5

2.6.3 Acidity Measurements . . . . . . . 5

2.6.4 Analysis of Anions . . . . . . . . . 6

2.6.4.1 Measurement for Sulfate Ion . 6

2.6.4.2 Measurement for Nitrate Ion. 6

2.6.4.3 Measurement for Fluoride Ion. 6

2.6.4.4 Measurement for Chloride Ion. 7

2.6.5 Analysis for Cations ........ . 7

2.6.5.1 Measurement of Ammonium Ion . 7

2.6.5.2 Metals by Atomic Absorption

and Flame Emission. • . . 8

2.6.5.3 Metals by Polarographic Analysis..... . . 8

3. ANALYTICAL RESUlTS . . . . . . . . . . . . 8

4. DISCUSSION . . . . . . . . . . . . 10

5. RECOMMENDED DILUTION PROCEDURE . . . . . . . . 11

6. ACKNOWLEDGEMENTS . • . • . • • . . • . • . 11 

John K. Taylor, E. R. Deardorff, R. A. Durst, E. J. Maientha1, T. C. Rains, and E. P. Scheide

\section{ABSTRACT}

The preparation of a series of reference materials for chemical analysis of natural precipitation is described. The materials consist of ampoules of concentrates which can be diluted to simulate naturally collected samples of rainwater. The analytical measurements made to verify the composition of the samples are also described.

\section{KEY WORDS}

Chemical analysis; rainwater analysis; reference materials.

\section{INTRODUCTION}

This report describes work done at the National Bureau of Standards to prepare reference materials needed for the evaluation of methodology and for the verification of data concerned with the analysis of rainwater and other forms of precipitation. Such measurements can provide valuable information on global pollution levels, atmospheric circulation, and geophysical phenomena when the data are validated. However, the reliability of such measurements is presently unknown.

In recognition of this situation, the National Bureau of Standards has investigated the problems of producing synthetic aqueous concentrates which simulate natural precipitation samples when quantitatively diluted.

The work reported here was initiated at the request of and supported by the Environmental Protection Agency under an Interagency Agreement and resulted in the preparation and analysis of a series of four concentrates of graded composition, and two additional sets of "unknowns" within the compositional range.

CONTRIBUTION OF THE NATIONAL BUREAU OF STANDARDS. NOT SUBJECT TO COPYRIGHT . 


\subsection{General Considerations}

A decision was made to produce four concentrates which could be diluted to simulate natural precipitation samples. The reference materials would consist of $10 \mathrm{ml}$ of appropriate solutions, sealed in ampoules, which would be quantitatively diluted to a final volume of $500 \mathrm{~m} 1$ by the user. The four concentration levels were chosen to represent the range of composition of samples ordinarily encountered in rainwater analysis.

The constituents and compositional levels recommended by EPA are given in table 1. However, some compromises had to be made in preparing the reference samples. From materials balance considerations, it was evident that there were missing constituents. There were also problems concerned with achieving specified values for gross parameters such as $\mathrm{pH}$, conductivity, and acidity when chemical constituents are specified.

A further problem is concerned with the actual synthesis of the samples. Natural processes cannot be duplicated in the laboratory. Hence, incompatibilities can occur during mixing of constituents which would not occur under natural conditions.

The recommended compositions were found to be deficient in anions. This could be rectified by addition of other anions but this would disturb the cation balance and also could conceivably cause compatibility problems. Furthermore, the basis for choice of the balancing anion was not clear. Accordingly, it was decided to use the values in table 1 as guidelines and to prepare the reference samples with the cationic constituents as the major consideration. The anionic constituents would approach the recommended levels as far as possible. The gross parameters would be permitted to assume values consistent with this approach.

A further complication is that of compatibility of constituents which is influenced by the order, rate of addition, and concentration of the individual constituents at time of addition to the bulk solution. The fact that the reference samples were to be 50 times more concentrated than the final solutions also complicated this problem, since compatibility needs to be achieved for the concentrates. 
In consideration of the problems outlined in Section 2.1, compromise concentration levels were adopted and experimental work was undertaken to investigate their feasibility. During this work, two problems were identified It was found difficult to retain iron at anywhere near the recommended level, so it was eliminated. Also there was some precipitation of lead in the most concentrated solution. Since this did not appear to be a major problem, it was decided to tolerate it, but to filter the solution before ampouling.

The chemicals used to prepare the reference materials are listed in table 2. In general, they were reagent grade chemicals and were believed to be of sufficient purity to permit calculation of the amount of constituent added without assaying them. However, it was later found that several of the hydrated salts were not the nominal compositions. Trace impurities in the chemicals are of no significance for the present situation. The selection of the chemicals was somewhat arbitrary to attain the desired anionic and cationic compositions. Laboratory grade distilled water was used for dilution purposes.

The amounts of chemicals used to prepare the bulk solutions are given in tables $3,4,5$, and 6 . For Solutions $A, C$, and $D$, half of the constituents were added to approximately 21 of water in a volumetric flask and then diluted to the mark. A second solution was prepared containing the remaining constituents. These solutions were combined and the resulting solution was filtered through a quantitative paper (S \& S 589 Blue Ribbon)*. In the case of Solution B, an additional volume of 21 of distilled water was added before filtering. The final solutions were stored in pyrex bottles of appropriate size prior to ampouling. No visible precipitation occurred during the storage period which was about 30 days.

\subsection{Ampouling}

The bulk solutions were transferred to ampoules using the automatic dispensing and sealing equipment of the Office of Standard Reference Materials. The ampoules used (Wheaton Cat. No. 176780) are made from borosilicate glass formulated to prevent a change of $\mathrm{pH}$ and to maintain the purity of the contents. They are pre-scored to eliminate the need for filing.

*Certain commercial materials and equipment are identified in this paper in order to adequately specify the experimental procedure. In no case does such identification imply recommendation or endorsement by the National Bureau of Standards, nor does it imply that the material or equipment identified is necessarily the best available for the purpose. 
The dispensing equipment pumps the solution from the storage vessel and reproducibility injects a pre-set volume into the ampoules. Ampoules randomly selected for analysis were also weighed to verify the reproducibility of the filling operation. No significant changes were detected during the entire filling operation for the four solutions, which was done during a three-hour period.

The dispensing equipment automatically flame-sealed the ampoules. These were then placed in their original shipping boxes, in the order of filling.

2.4 Numbering Sequence

The ampoules were labeled and numbered in the following sequences:

$$
\begin{aligned}
& \text { Solution A - 75001A to } 75320 \mathrm{~A} \\
& \text { Solution B }-75001 \mathrm{~B} \text { to } 75520 \mathrm{~B} \\
& \text { Solution C } \\
& \text { Solution D }-75001 \mathrm{C} \text { to } 75320 \mathrm{C} \\
& \text { Solution to } 75320 \mathrm{D}
\end{aligned}
$$

Twenty samples were randomly selected from each lot for chemical analysis. The remainder of the ampoules were delivered to EPA.

In addition to the ampoules noted above, additional ampoules amounting to approximately 40 in each lot were filled, depending upon the amount of solution available. These ampoules were also numbered in a continuation of the same sequences and will be retained at NBS for further study.

\subsection{Analysis of Bulk Solutions}

The bulk solutions were analyzed for their cationic constituents by atomic absorbtion and flame emission spectrometry. The results, reported in tables 7 to 10 indicate that the desired concentration levels had been acheived, except in the case of lead in Solution $D$ where it was known that some initial precipitation had occurred. The data are also useful to evaluate any long-term deterioration of the samples, either by loss or leaching processes.

\subsection{Analysis of Ampoules}

Twenty ampoules randomly selected from each lot, and addicional ampoules randomly selected from the excess of the lots were analyzed as will be described in the following sections. The analysts also weighed the ampoules before and after delivery of their contents to evaluate the reproducibility of the filling operation. 


\section{$2.6 .1 \mathrm{pH}$ Measurements}

The $\mathrm{pH}$ measurements were made on diluted samples of the concentrate ( $1 \mathrm{ml}$ sample $+49 \mathrm{ml} \mathrm{H}_{2} \mathrm{O}$ ). The combination $\mathrm{pH}$ electrode was calibrated with $\mathrm{pH} 4.01$ and 7.00 buffers and the sample pH readings were taken directly from the digital $\mathrm{pH}$ meter display. Since the water used for diluting the samples was in approximate equilibrium with ambient $\mathrm{CO}_{2}$, the values found for the $\mathrm{pH}$ were consistent with what would be expected for air-equilibrated water, i.e., $\mathrm{pH} 5.6$ to 6.0 , and indicate that there is little acid-base character to the samples themselves.

\subsubsection{Conductivity Measurements}

The conductivity measurements were made on the same diluted samples as the $\mathrm{pH}$ determinations. The cell constant, $\mathrm{k}$, was determined using $0.01 \mathrm{M}$ and $0.001 \mathrm{M} \mathrm{KCl}$ solutions having specific conductances, $L$, of 0.00141 and 0.000147 $\mathrm{S} \cdot \mathrm{cm}^{-1}$. The specific conductance of the sample solutions was calculated from the measured resistance at a frequency of $1 \mathrm{kHz}$ by the equation:

$$
L=\frac{k}{R}=\frac{0.0307 \mathrm{~cm}^{-1}}{R}
$$

\subsubsection{Acidity Measurements}

Measurement of acidity was made by the method described in the EPA Manual of Methods for Chemical Analysis of Water and Wastes. The $\mathrm{pH}$ of a $10 \mathrm{ml}$ sample was measured followed by addition of standardized sulfuric acid to $\mathrm{pH} 4$. Hydrogen peroxide $(30 \%)$ was added and the solution was boiled for several minutes. After cooling, it was titrated with standardized sodium hydroxide to $\mathrm{pH} 8.2$ and the acidity was calculated as mg/liter $\mathrm{CaCO}_{3}$.

Measurements were made on the concentrates to obtain increased precision and also on the reconstituted rainwater in the case of Solution D. The latter measurements were consistent with calculations based on a 50 fold dilution of the concentrate. The values reported in tables 7-10 are calculated for the reconstituted sample on the basis of a 50 fold dilution of the concentrate. 
2.6.4.1 Measurements for Sulfate Ion

The sulfate determinations were accomplished by titration with lead nitrate solution using the lead ionselective electrode as the end-point detector. The indirect determination of sulfate is based on the formation of $\mathrm{PbSO}_{4}$ which is quantified by measurements with a lead electrode. The measurements were carried out in 80 percent by volume isopropanol using a double-junction reference electrode. The sulfate analyses were performed using a Gran plot of the titration standards of known amounts of sulfate with standard lead nitrate. These were compared to the unknown samples. The Gran plot technique permits titration +measurements to be taken beyond the equivalence point where $\mathrm{Pb}^{++}$is in excess and the electrode responds optimally. It also results in a linear extrapolation to the end-point which simplifies the data interpretation. Before each sulfate determination, a blank was run to check the electrode response and to determine the blank correction. Also, the electrode was repolished after each sample was run to remove surface contamination. Without re-polishing, the electrode response becomes progressively slower and non-ideal. The concentrates were initially diluted, if necessary, to a sulfate concentration of approximately $10^{-5} \mathrm{M}$. Two milliliters of these were diluted with $8 \mathrm{ml}$ of isopropanol prior to titration. Triplicate analyses were done on each sample and standard.

\subsubsection{Measurements for Nitrate}

Measurements for nitrate were made by the Brucine Method following the procedure in ASTM Method D 992-71, Nitrate Ion in Water. Nitrate ion reacts with brucine in strong sulfuric acid to develop a yellow color. A calibration curve was made with pure potassium nitrate to obtain a smooth curve in the range 0 to $250 \mathrm{\mu g} / 25 \mathrm{ml}$ where the solution does not follow Beer's Law. The absorbance was read at $410 \mathrm{~nm}$, using $1 \mathrm{~cm}$ cells. A sample size of $5 \mathrm{ml}$ was used in these measurements.

\subsubsection{Measurement of Fluoride Ion}

The fluoride determinations were performed by direct potentiometry on ampoule samples diluted 1:2 with TISAB (total ionic strength adjustment buffer). Calibration standards containing 2,20 , and $100 \mathrm{ppm} \mathrm{F}^{-}$were also prepared by $1: 2$ dilution with TISAB to permit direct reading of the sample fluoride concentrations. The electrode response was Nernstian over this range and the emf readings on both samples and standards were generally stable. 
Two analytical techniques were used to determine the chloride content of these samples. For the higher concentrations (samples "C", "D"), an automatic chloride titrator was used. This method is based on the amperometric generation of silver ions in situ which is automatically stopped at the end point by a potentiometric detector. Duplicate, and sometimes triplicate, 100- $\mu$ samples were used and the reproducibility between duplicates was generally better than 1 percent. The chloride titrator was calibrated with 500 and $1000 \mathrm{ppm}$ standards.

Samples "A" and "B" did not contain sufficient chloride to activate the potentiometric sensor in the titrator, and it was necessary to determine the chloride in these samples by direct potentiometry using a chloride ion-selective electrode. Calibration standards containing 1, 10, and $100 \mathrm{ppm}$ were used and, over the sample concentration range, the response was 1 inear and approximatly Nernstian ( $54.2 \mathrm{mV} / \mathrm{pCl})$. The precision of these measurements was not good, being about \pm 5 percent for the "B" samples and \pm 10 percent for the "A" samples. It is assumed that the observed deviations are due to measurement imprecision rather than actual differences between ampoules.

\subsubsection{Analysis for Cations}

2.6.5.1 Measurement of Ammoniurn Ion

Measurement for ammonium ion were made by two methods. An ammonia electrode was used to determine ion concentration by direct potentiometry. The sample and standard solutions $(2,20$, and $200 \mathrm{ppm})$ were diluted $1: 2$ with $1.0 \mathrm{M}$ $\mathrm{NaOH}$ to convert all of the $\mathrm{NH}_{4}^{+}$to $\mathrm{NH}_{3}$ which is measured by the electrode. Although the electrode response over the concentration range of interest was good $\left(55.5 \mathrm{mV} / \mathrm{pNH}_{3}\right)$, there was excessive electrode drift during the measurements, possibly due to the difficulty in measuring a volatile component in a very small volume of solution. As a result, little confidence was ascribed to the data.

The second technique consisted of chemical measurement according to the procedure given in the following reference: C. O. Willits and C. L. Ogg, "1949 Report of Standardization of Microchemical Methods, Micro Kjeldahl Nitrogen Determinations," USDA Eastern Regional Research Laboratory, Philadelphia, PA. A micro-Kjeldahl steam distillation apparatus was used to separate the ammonia released by sodium hydroxide, which was trapped in boric acid. The ammonia was titrated with standardized $0.01 \mathrm{~N}$ hydrochloric acid using methyl purple indicator. Both $5 \mathrm{ml}$ and $10 \mathrm{ml}$ samples were used for these measurements. 
Because of the problems which were encountered in the analysis using the ion-selective electrode, the values obtained using this method were used only for evaluation of homogeneity. Accordingly, the values reported in tables 7 to 10 are based on the second method only.

\subsubsection{Metals by Atomic Absorption and Flame Emission Spectrometry}

All of the metallic cations were measured by atomic absorption or flame emission spectrometry. Measurements were made both on the bulk solution and on the ampoules. The contents of an ampoule were quantitatively transferred to a $100 \mathrm{ml}$ volumetric flask. After addition of $1 \mathrm{ml}$ of purified nitric acid, the solution was diluted to the calibrated volume. Emission or absorption measurements were made in duplicate. Calibration standards were made by dissolution of pure salts or pure metals.

2.6.5.3 Metals by Polarographic Analysis

Polarographic measurements were made for selected elements, on reconstituted samples, i.e. a solution resulting from dilution of the contents of an ampoule to a final volume of $500 \mathrm{ml}$.

Measurements of copper, lead, cadmium, nickel and zinc were made on the diluted samples in the following manner. Aliquots of $100 \mathrm{ml}$ of the diluted samples were evaporated to dryness in quartz beakers, after addition of a few drops of perchloric acid. After a second evaporation with hydrochloric acid, the residues were redissolved in $2 \mathrm{ml}$ of supporting electrolyte. For the case of copper, lead, and cadmium, the supporting electrolyte was ammonium acetate acetic acid. A supporting electrolyte of pyridine pyridinium sulfate was used for measurement of njckel and zinc. Measurements were made with a cathode-ray polarograph. Calibration standards and blanks were carried through the procedure.

Additional ampoules were analyzed similarly, except they were also rinsed with nitric acid and these rinsings were included in the analysis.

\section{ANALYTICAL RESULTS}

The analytical results obtained for the four reference materials are summarized in tables $7,8,9$, and 10 . These include data for the bulk solutions, analysis of individual ampoules, and measurements on the reconstituted solutions in several cases. However, all data are reported on the basis of the reconstituted solutions (dilution of $10 \mathrm{ml}$ to a final volume of $500 \mathrm{ml}$ ). The columns labelled "Synthesis" contain values calculated from the composition of the solutions as prepared. 
The last column of each table lists the recommended values for each parameter based on a "best estimate" in consideration of the synthesis values and the analytical limits of uncertainty. When the two values are in essential agreement, the synthesis values are recommended. This is the case for most of the parameters. The analytic values are recommended in several cases where uncertainties in the compositions of the starting materials, or loss or gain of a constituent was found or believed to be a reasonable explanation of the discrepancy.

All of the cadmium values are larger than expected. In view of the good agreement between the two measurement techniques, the discrepancy is believed to be due to nonstoichiometery of the hydrates used for preparation of the solutions, hence the measured values are recommended. The values found by polarographic measurement of copper in the reconstituted solutions are slightly smaller than expected. Since the synthesis values were found for solutions resulting from rinsing the ampoules with acid, it is concluded that a small loss of copper has resulted from interaction with the ampoules. Because acid rinsing is not permissible, the measured values are recommended. The values found for lead by two techniques are also lower than expected. Again, values in agreement with the bulk solution were found for ampoules rinsed with acid. Accordingly, it is concluded that losses have occurred as the result of interaction with the ampoule walls, so the measured values are again recommended.

The values found for calcium in samples $B$ and $D$ are somewhat lower than expected but agreement was found in the case of samples $A$ and $C$. In view of this latter agreement and the confidence in the analytical procedure, the measured values are recommended for solutions $B$ and D.

The measured values for fluoride are low by a few percent for all solutions except A although the differences are barely significant. However, in view of the care exercised in making the measurements, it is believed that the measured values are more likely and they are recommended for these solutions.

The only other significant departure from the expected values is that for sulfate in solution $B$. When the discrepancy was noticed, the measurement was repeated to verify the analytical value which is recommended.

It is not possible to assign uncertainty limits to the recommended values, because of limited experience with these materials. In most cases, the analytical measurements were 
made with techniques used at NBS that are capable of providing data reliable to within 2 percent. However, stability problems may be an overriding factor of unknown magnitude. The best statement that can be made at present is that the data are believed to be useful to two significant figures.

\section{DISCUSSION}

The suitability of the samples to serve as reference materials or for intercalibration of measurement laboratories is based upon several types of information. Each ampoule contains the same weight of solution within close limits. Weighing of eighty ampoules indicated an average weight content of $9.963 \mathrm{~g}$ with a standard deviation of $0.005 \mathrm{~g}$. Accordingly, it is clear that variations in the total amount of the contents are of no concern.

Measurements on replicate ampoules in each series were also made for most of the parameters to obtain information on possible variation between samples. These ranged from duplicates for 2 parameters to septuplicates on 9 parameters. No variations larger than the expected measurement variations were found. Accordingly, it is believed that all of the samples in a given series are reasonably identical in composition.

Because the materials consist of filtered solutions, uniformity of composition between ampoules would be expected, provided the contents are stable. It would have been preferred to study the stability over an extended period of time but the time schedule did not permit this. Accordingly, the long-term stability has not been established.

A few minor stability problems are evident from inspection of the data in tables 7 to 10 . The values for sodium appear to be increasing, perhaps due to leaching from the walls of the ampoules. The values for copper and lead appear to have decreased since ampouling. It was found that the loss can be regained by an acid wash but this is not a permissible operation. However, the samples appear to be satisfactory for collaborative studies, especially if all measurements are carried out within a reasonably comparable period of time.

Samples have been retained by NBS and these will be analyzed after a suitable period of time to further evaluate their stability. 
The samples consist of ampoules of concentrate which simulate rainwater, when diluted to $500 \mathrm{ml}$. The ampoules are pre-scored at the constriction to facilitate breaking off the tip. Glassware should be thoroughly cleaned and rinsed with distilled water before use. The distilled water used for rinsing and dilution should be of the highest quality since any impurity will add to the constituents of the sample. The recommended procedure for preparation of the test sample is as follows:

1. Rinse the outside of the ampoule to remove dust and allow to air dry.

2. Hold ampoule in a vertical position, tip up, and gently tap to transfer any liquid from the tip to the body of the ampoule.

3. Hold ampoule with a paper towel (precaution to prevent injury to hand) and snap off the tip at the scored constriction.

4. Place a clean funnel in the neck of a clean $500 \mathrm{mI}$ volumetric flask and transfer the contents of the ampoule, with gently shaking as required to facilitate removal of liquid.

5. Rinse the ampoule two times with distilled water and transfer the rinsings to the flask.

6. Add distilled water to the flask to dilute to the graduation mark, and mix contents thoroughly.

7. Treat the resulting solution with the same care and in the same manner as a sample of natural rainwater.

\section{ACKNOWLEDGEMENTS}

This work was done under the general supervision of John K. Taylor. Mr. Erle R. Deardorff prepared the solutions and performed analyses for nitrate, ammonia, and acidity. Mr. T. C. Rains and Ms. M. A. Waguespack performed the atomic absorbtion and flame emission measurements. Dr. R. A. Durst made the measurements of $\mathrm{pH}$, conductance, and analyses for fluoride, chloride, and ammonium by the ion-selective electrode. Dr. E. P. Scheide anlyzed the samples for sulfate ion. Ms. E. J. Maienthal made polarographic measurements on the diluates for five metals. Mr. W. P. Reed of the NBS Office of Standard Reference Materials was responsible for the ampouling of the samples. 
Table 1. Proposed Reference Standards

Sample

Constituent (unit of measurement)

$\mathrm{pH}$

Conductivity $\left(\mu \mathrm{Scm}^{-1}\right)$

Acidity ( $\mu$ eq)

$\mathrm{SO}_{4}(\mathrm{~S})^{1}(\mathrm{mg} / 1)$

$\mathrm{NO}_{3}^{-}(\mathrm{N})^{2}(\mathrm{mg} / 1)$

$\mathrm{NH}_{4}^{+}(\mathrm{N})^{2}(\mathrm{mg} / 1)$

$\mathrm{F}^{-}(\mathrm{mg} / 1)$

$\mathrm{Cl}^{-}(\mathrm{mg} / 1)$

$\mathrm{Na}^{+}(\mathrm{mg} / 1)$

$\mathrm{K}^{+}(\mathrm{mg} / 1)$

$\mathrm{Ca}^{++}(\mathrm{mg} / 1)$

$\mathrm{Mg}^{++}(\mathrm{mg} / 1)$

$\mathrm{Zn}^{++}(\mathrm{mg} / 1)$

$\mathrm{Cd}^{++}(\mathrm{mg} / 1)$

$\mathrm{Cu}^{++}(\mathrm{mg} / 1)$

$\mathrm{Ni}^{++}$(mg/1)

Fe (mg/1)

$\mathrm{Pb}^{++}(\mathrm{mg} / 1)$

$\mathrm{Mn}^{++}(\mathrm{mg} / \mathrm{l})$
A $\quad$ B

Value

5.70

35.0

.1

1.0

.1

.1

.1

.1

.1

.05

.1

.05

.02

.03

.05

.02

.05

.02

.05

1.0
$\underline{C}$

D

Value

4.90

50.0

1.0

3.0

1.0

.1

1.0

1.0

.1

1. 0

1. 0

.1

.1

.1

.1

.1

.1

.08 $\frac{\text { Value }}{4.50}$

65.0

5.0

5.0

5.0

5.0

.2

5.0

5. 0

1.0

5.0

5.0

.3

.5

.2

. 5

.2

.2

.1
1.0

1.0

.5

Value

4.00

90.0

10.0

10.0

10.0

10.0

.3

10.0

10.0

5.0

10.0

10.0

.6

.4

. 3

.2 
Table 2. Chemicals Used for Preparation of Reference Solutions

Chemical

Calcium Chloride

Calcium Sulfate

Magnesium Chloride

Magnesium Sulfate

Zinc Chloride

Zinc Nitrate

Cadmium Chloride

Cadmium Nitrate

Cupric Chloride

Cupric Nitrate

Cupric Sulfate

Nickel Nitrate

Nickelous Sulfate

Lead Nitrate

Manganese Chloride

Ammonium Chloride

Ammonium Sulfate

Sodium Fluoride

Sodium Nitrate

Sodium Sulfate

Potassium Chloride

Potassium Nitrate

Potassium Sulfate
Formula

$\mathrm{CaCl}_{2} \cdot 2 \mathrm{H}_{2} \mathrm{O}$

$\mathrm{CaSO}_{4}$

$\mathrm{MgCl}_{2} \cdot 6 \mathrm{H}_{2} \mathrm{O}$

$\mathrm{MgSO}_{4}$

$\mathrm{ZnCl}_{2}$

$\mathrm{Zn}\left(\mathrm{NO}_{3}\right)_{2} \cdot 6 \mathrm{H}_{2} \mathrm{O}$

$\mathrm{CdCl}_{2} \cdot 2 \frac{1}{2} \mathrm{H}_{2} \mathrm{O}$

$\mathrm{Cd}\left(\mathrm{NO}_{3}\right)_{2} \cdot 4 \mathrm{H}_{2} \mathrm{O}$

$\mathrm{CuCl}_{2} \cdot 2 \mathrm{H}_{2} \mathrm{O}$

$\mathrm{Cu}\left(\mathrm{NO}_{3}\right)_{2} \cdot 3 \mathrm{H}_{2} \mathrm{O}$

$\mathrm{CuSO}_{4} \cdot 5 \mathrm{H}_{2} \mathrm{O}$

$\mathrm{Ni}\left(\mathrm{NO}_{3}\right)_{2} \cdot 6 \mathrm{H}_{2} \mathrm{O}$

$\mathrm{NiSO}_{4} \cdot 6 \mathrm{H}_{2} \mathrm{O}$

$\mathrm{Pb}\left(\mathrm{NO}_{3}\right)_{2}$

$\mathrm{MnCl}_{2} \cdot 4 \mathrm{H}_{2} \mathrm{O}$

$\mathrm{NH}_{4} \mathrm{Cl}$

$\left(\mathrm{NH}_{4}\right)_{2} \mathrm{SO}_{4}$

$\mathrm{NaF}$

$\mathrm{NaNO}_{3}$

$\mathrm{Na}_{2} \mathrm{SO}_{4}$

$\mathrm{KC} 1$

$\mathrm{KNO}_{3}$

$\mathrm{K}_{2} \mathrm{SO}_{4}$
Source

Mallinckrodt Analytical Reagent Hammond Drierite Company

Mallinckrodt Analytical Reagent

B \& A Reagent

Fisher Certified

Baker Analyzed

Baker Analyzed

Fisher Certified

Fisher Certified

Baker Analyzed

Fisher Certified

Mallinckrodt Analytical Reagent

B \& A Reagent

Baker Analyzed

Mallinckrodt Analytical Reagent Baker Analyzed

Mallinckrodt Analytical Reagent

Fisher Certified

Baker Analyzed

Mallinckrodt Analytical Reagent

Fisher Certified

Baker Analyzed

Fisher Certified 
Table 3. Chemicals Used to Prepare Solution A (Weight in $\mathrm{mg}$ to prepare 4 liters)

\begin{tabular}{|c|c|c|c|c|c|c|}
\hline & $\underline{\mathrm{mg}}$ & $\begin{array}{l}\mathrm{mg} \\
\underline{S O}_{4-}^{=}\end{array}$ & $\begin{array}{l}\mathrm{mg} \\
\underline{N O}_{\overline{3}}-\end{array}$ & $\begin{array}{l}\mathrm{mg} \\
\mathrm{F}-\end{array}$ & $\begin{array}{l}\mathrm{mg} \\
\mathrm{C} 1^{-}\end{array}$ & $\begin{array}{c}\mathrm{mg} \\
\text { Reagent } \\
\end{array}$ \\
\hline $\mathrm{Ca}^{++}$ & 19.77 & 47.38 & & & & 67.15 \\
\hline $\mathrm{Mg}^{++}$ & 20.83 & 82.32 & & & & 103.15 \\
\hline $\mathrm{Zn}^{++}$ & 4.25 & & & & 4.60 & 8.85 \\
\hline $\mathrm{Cd}^{++}$ & 5.18 & & & & 3.27 & 10.53 \\
\hline $\mathrm{Cu}^{++}$ & 10.33 & 15.61 & & & & 40.59 \\
\hline $\mathrm{Ni}^{++}$ & 4.11 & 6.72 & & & & 18.40 \\
\hline $\mathrm{Pb}^{++}$ & 4.51 & & 2.70 & & & 7.21 \\
\hline $\mathrm{Mn}^{++}$ & 10.35 & & & & 13.36 & 37.30 \\
\hline $\mathrm{NH}_{4}^{+}$ & 22.71 & 60.60 & & & & 83.31 \\
\hline $\mathrm{Na}^{+}$ & 25.53 & & & 21.10 & & 46.64 \\
\hline $\mathrm{K}^{+}$ & 12.51 & & 19.83 & & & 32.34 \\
\hline
\end{tabular}


Table 4. Chemicals Used to Prepare Solution B (Weight in $\mathrm{mg}$ to prepare 6 1iters)

$\underline{\mathrm{mg}}$

$\mathrm{Ca}^{++} \quad 150.54$

$\mathrm{Mg}^{++} \quad 162.17 \quad 640.93$

$\mathrm{Zn}^{++} \quad 29.86$

$\mathrm{Cd}^{++} \quad 29.64$

$\mathrm{Cu}^{++} \quad 30.67$

$\mathrm{Ni}^{++} \quad 31.11$

$\mathrm{Pb}^{++}$

$\mathrm{Mn}^{++}$

$\mathrm{NH}_{4}^{+}$

$\mathrm{Na}^{+}$

$\mathrm{K}^{+}$

$\mathrm{Na}^{+}$

$\mathrm{Na}^{+}$

24.37

$147.62 \quad 393.91$

$93.49 \quad 195.31$

30.62

20.59

36.91

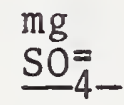

№-

$\underline{\mathrm{mg}}$ $\mathrm{mg}$

C1-

266.32

32.39

18.69

59.84

65.71

18.98
18.98

31.45

27.76

55.52

30.50 $\mathrm{mg}$

$\underline{\text { Reagent }}$

552.1

803.1

62.26

60.21

116.6

154.1

50.70

87.79

541.9

288.8

58.38

76.12

67.43 
Table 5. Chemicals Used to Prepare Solution C (Weight in $\mathrm{mg}$ to prepare 4 liters)

\begin{tabular}{|c|c|c|c|c|c|c|}
\hline & $\underline{\mathrm{mg}}$ & $\begin{array}{l}\mathrm{mg} \\
\mathrm{SO}_{4}=\end{array}$ & $\begin{array}{l}\mathrm{mg} \\
\mathrm{NO}_{\overline{3}}\end{array}$ & $\begin{array}{l}\mathrm{mg} \\
\mathrm{F}^{-}\end{array}$ & $\begin{array}{l}\mathrm{mg} \\
\mathrm{C} 1-\end{array}$ & $\begin{array}{c}\mathrm{mg} \\
\text { Reagent }\end{array}$ \\
\hline $\mathrm{Ca}^{++}$ & 246.15 & 589.95 & & & & 836.1 \\
\hline $\mathrm{Mg}^{++}$ & 145.71 & & & & 425.09 & 1219.0 \\
\hline $2 \mathrm{n}^{++}$ & 61.29 & & 116.25 & & & 278.9 \\
\hline $\mathrm{Cd}^{++}$ & 100.80 & & & & 63.59 & 204.8 \\
\hline $\mathrm{Cu}^{++}$ & 39.88 & & & & 44.50 & 107.0 \\
\hline $\mathrm{Ni}^{++}$ & 101.27 & 165.70 & & & & 453.4 \\
\hline $\mathrm{Pb}^{++}$ & 39.23 & & 23.48 & & & 62.71 \\
\hline $\mathrm{Mn}^{++}$ & 19.96 & & & & 25.77 & 71.92 \\
\hline $\mathrm{NH}_{4}^{+}$ & 490.77 & & & & 966.5 & 1458.4 \\
\hline $\mathrm{Na}^{+}$ & 440.60 & & 1188.23 & & & 1629.0 \\
\hline $\mathrm{K}^{+}$ & 201.35 & 247.33 & & & & 448.7 \\
\hline $\mathrm{Ja}^{+}$ & 48.50 & & & 40. & & 88.6 \\
\hline
\end{tabular}


Table 6. Chemicals Used to Prepare Solution D (Weight in $\mathrm{mg}$ to prepare 4 liters)

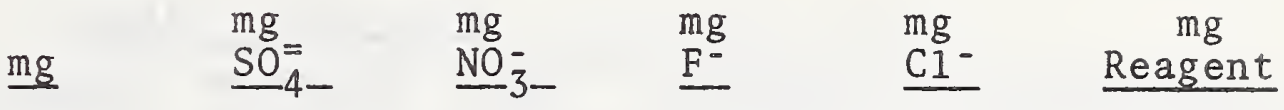

$\mathrm{Ca}^{++} \quad 640.8$

$\mathrm{Mg}^{++} \quad 189.3$

$\mathrm{Zn}^{++} \quad 122.1$

$\mathrm{Cd}^{++} \quad 200.7$

$\mathrm{Cu}^{++} \quad 80.2$

$\mathrm{Ni}^{++} \quad 201.4$

$\mathrm{Pb}^{++} \quad 58.8$

$M n++\quad 40.1$

$\mathrm{NH}_{4}^{+} \quad 924.3$

$\mathrm{Na}^{+} \quad 597.7 \quad 1249.0$

$\begin{array}{lll}\mathrm{K}^{+} & 611.5 & 751.1\end{array}$

$\mathrm{Na}^{+} \quad 410.3$

$\mathrm{Na}^{+}$

72.8
$1133.7 \quad 2350.1$

$552.4 \quad 1584.0$

231.6

221.4

156.6

425.5

35.2

1821

1106.6

60.2
51.8
555.6

550.7

305.1

997.9

93.99

144.5

2747.0

1846.9

1362.6

1517.1

133.0 
Table 7. Analytical Values for Reconstituted Samples

\begin{tabular}{|c|c|c|c|c|c|}
\hline \multirow[b]{2}{*}{ Measured } & \multirow[b]{2}{*}{ Synthes is } & \multicolumn{3}{|c|}{ Analytical Values } & \multirow{2}{*}{$\begin{array}{c}\text { Recommended } \\
\text { Values* }\end{array}$} \\
\hline & & Bu. $1 \mathrm{k}$ & Ampoules & Diluate & \\
\hline $\mathrm{pH}$ & & & & 6.18 & 6.18 \\
\hline Conductivity** & & & & 5.8 & 5.8 \\
\hline Acidity*** & & 0.49 & & & 0.49 \\
\hline $\mathrm{SO}_{4}=(\mathrm{S})$ & 361 & & 342 & & 361 \\
\hline $\mathrm{NO}_{3}^{-}(\mathrm{N})$ & 26 & 26 & 26 & & 26 \\
\hline $\mathrm{NH}_{4}^{+}(\mathrm{N})$ & 89 & 81 & 84 & & 89 \\
\hline $\mathrm{F}^{-}$ & 102 & & 103 & & 102 \\
\hline $\mathrm{C} 1^{-}$ & 106 & & 136 & & 106 \\
\hline $\mathrm{Na}^{+}$ & 128 & 134 & 153 & & 153 \\
\hline $\mathrm{K}^{+}$ & 63 & 68 & & & 63 \\
\hline $\mathrm{Ca}^{++}$ & 99 & 96 & & & 99 \\
\hline $\mathrm{Mg}^{++}$ & 104 & 86 & & & 86 \\
\hline $\mathrm{Zn}^{++}$ & 21 & 19 & 20 & & 21 \\
\hline $\mathrm{Cd}^{++}$ & 26 & 30 & & & 30 \\
\hline $\mathrm{Cu}^{++}$ & 52 & 53 & & & 52 \\
\hline $\mathrm{Ni}^{++}$ & 21 & 23 & & & 21 \\
\hline $\mathrm{Pb}^{++}$ & 23 & 20 & 18 & & 18 \\
\hline $\mathrm{Mn}^{++}$ & 52 & 55 & 53 & & 52 \\
\hline
\end{tabular}

* Data believed useful to 2 significant figures

** $\quad \mathrm{HS} \cdot \mathrm{cm}^{-1}$ reconstituted solution

$* * * \mathrm{mg} / 1 \mathrm{CaCO}_{3}$

All other units, $\mu g / 1$ reconstituted solution 
Table 8. Analytical Values for Reconstituted Samples Sample B

Analytical Values

Acid Recommended

Measured Synthesis Bulk Ampoules Diluate Rinse Values*

$\mathrm{pH}$

Conductivity**

Acidity***

$\mathrm{SO}_{4}^{=}(\mathrm{S})$

$\mathrm{NO}_{3}^{-}(\mathrm{N})$

$\mathrm{NH}_{4}^{+}(\mathrm{N})$

$\mathrm{F}^{-}$

$\mathrm{Cl}^{-}$

$\mathrm{Na}^{+}$

$\mathrm{K}^{+}$

$\mathrm{Ca}^{++}$

$\mathrm{Mg}^{++}$

$2 n^{++}$

$\mathrm{Cd}^{\neq+}$

$\mathrm{Cu}^{++}$

$\mathrm{Ni}^{++}$

$\mathrm{Pb}^{++}$

$\mathrm{Mn}^{++}$

* Data believed useful to 2 significant figures

** $\mu \mathrm{S} \cdot \mathrm{cm}^{-1}$

*** $\mathrm{mg} / 1 \mathrm{CaCO}_{3}$

A11 other units, $\mu \mathrm{g} / 1$ reconstituted solution

p Polarographic measurement
6.15

18.3

1188

150

364

96

1080

516

516

102

442

456

94

$94^{\mathrm{p}}$

$96^{\mathrm{p}}$

95

$116^{\mathrm{p}} \quad 116^{\mathrm{p}}$

116

$102 \quad 107$

${ }_{88}{ }^{\mathrm{p}} \quad{ }_{101^{\mathrm{p}}}$

88

$103^{\mathrm{p}} \quad 104^{\mathrm{p}}$

104

92

${ }_{88}{ }^{\mathrm{P}} \quad 104^{\mathrm{P}}$

88

83

6.15

18.3

0.50

1188

150

382

96

1255

$104 \quad 109$

81

84 
Table 9. Analytical Values for Reconstituted Samples

Sample C

\section{Analytical Values}

Acid Recommended Measured Synthesis Bulk Ampoules Diluate Rinse Values*

$\mathrm{pH}$

Conductivity**

Acidity***

$\mathrm{SO}_{4}=(\mathrm{S})$

$\mathrm{NO}-\overline{3}(\mathrm{~N})$

$\mathrm{NH}_{4}^{+}(\mathrm{N})$

$\mathrm{F}^{-}$

$\mathrm{C}^{-}$

$\mathrm{Na}^{+}$

$\mathrm{K}^{+}$

$\mathrm{Ca}^{++}$

$\mathrm{Mg}^{++}$

$\mathrm{Zn}++$

$\mathrm{Cd}^{++}$

$\mathrm{Cu}^{++}$

$\mathrm{Ni}^{++}$

$\mathrm{Pb}^{++}$

$\mathrm{Mn}^{++}$
1672

$1499 \quad 1500$

$1909 \quad 1890$

200

7627

$2446 \quad 2420$

$1007 \quad 1020$

$1231 \quad 1216$

729

722

307

314

500

574

200

198

506

518

196

170

100

6.20

6.20

59.8

59.8

2.46

2.46

1645

1672

1499

1909

195

7627

7666

2460

1007

1231

729

312

$309^{p}$

$309^{p}$

307

$578^{p}$

$578^{\mathrm{P}}$

578

$192^{\mathrm{p}}$

$198^{\mathrm{p}}$

200

$506^{\mathrm{P}}$

${ }_{507} \mathrm{p}$

506

164

$152^{\mathrm{p}}$

$169^{\mathrm{P}}$

152

101

100

* Data believed useful to 2 significant figures

** $\mu \mathrm{S} \cdot \mathrm{cm}^{-1}$

$* * * \quad \mathrm{mg} / \mathrm{I} \mathrm{CaCO}_{3}$

Al1 other units, $\mu \mathrm{g} / 1$ reconstituted solution

p Polarographic measurement 
Table 10. Analytical Values for Reconstituted Samples Sample D

\section{Analytical Values}

Acid Recommended

Measured Synthesis Bulk Ampoules Diluate Rinse Values*

$\mathrm{pH}$

Conductivity**

Acidity***

$\mathrm{SO}_{4}=$

(S)

$\mathrm{NO}_{3}^{-}(\mathrm{N})$

$\mathrm{NH}_{4}^{+}(\mathrm{N})$

$\mathrm{F}^{-}$

$\mathrm{Cl}-$

$\mathrm{Na}^{+}$

$\mathrm{K}^{+}$

$\mathrm{Ca}^{++}$

$\mathrm{Mg}^{++}$

$\mathrm{Zn}++$

$\mathrm{Cd}^{++}$

$\mathrm{Cu}^{++}$

$\mathrm{Ni}^{++}$

$\mathrm{Pb}^{++}$

$\mathrm{Mn}^{++}$

** $\quad \mu \mathrm{S} \cdot \mathrm{cm}^{-1}$

$* * * \quad \mathrm{mg} / 1 \mathrm{CaCO}_{3}$

All other units, $\mu \mathrm{g} / 1$ reconstituted solution

$\mathrm{p} \quad$ Polarographic measurement
6.07

6.07

117

117

4.71

3374

3333

2500

2457

3524

3595

296

296

16922

17790

5444

5444

3058

2840

922

632

$610^{p}$

$610^{\mathrm{p}}$

610

$1010^{\mathrm{p}}$

$1010^{\mathrm{p}}$

1010

$393^{\mathrm{p}}$

$410^{\mathrm{p}}$

393

$1040^{p} \quad 1040^{p}$

1007

110

$120^{\mathrm{p}}$

110

200

4. 71

.


NBS.114A (REV. 7.73)

\begin{tabular}{|c|c|c|c|}
\hline $\begin{array}{l}\text { U.S. DEPT. OF COMM. } \\
\text { BIBLIOGRAPHIC DATA } \\
\text { SHEET }\end{array}$ & $\begin{array}{l}\text { 1. PUBLICATION OR REPORT NO. } \\
\text { NBSIR } 75-958\end{array}$ & $\begin{array}{l}\text { 2. Gov't Accession } \\
\text { No. }\end{array}$ & 3. Recipient's Accession No. \\
\hline \multirow{2}{*}{\multicolumn{3}{|c|}{$\begin{array}{l}\text { 4. TITLE AND SUBTITLE } \\
\text { Simulated Precipitation Reference Materials }\end{array}$}} & $\begin{array}{l}\text { 5. Publication Date } \\
\text { October } 1975\end{array}$ \\
\hline & & & 6. Performing Organization Code \\
\hline $\begin{array}{l}\text { 7. AU'HOR(S) J. K. } \\
\text { E. J. Maienthal }\end{array}$ & $\begin{array}{l}\text { ylor, E. R. Deardorff } \\
\text { T. C. Rains, and E. F }\end{array}$ & $\begin{array}{l}\text { R. A. Durst, } \\
\text { Scheide }\end{array}$ & B. Performing Organ. Report No. \\
\hline \multicolumn{3}{|c|}{$\begin{array}{l}\text { NATIONAL BUREAU OF STANDARDS } \\
\text { DEPARTMENT OF COMMERCE } \\
\text { WASHINGTON, D.C. } 20234\end{array}$} & \begin{tabular}{|l} 
10. Project/Task/Work Unit No. \\
3104533 \\
11. Contract/Grant No.
\end{tabular} \\
\hline \multirow{2}{*}{\multicolumn{3}{|c|}{$\begin{array}{l}\text { 12. Sponsoring Organization Name and Complete Address (Street, City, State, ZIP) } \\
\text { Office of Research and Development } \\
\text { National Environmental Research Center } \\
\text { Environmental Protection Agency } \\
\text { Research Triangle'Park, NC } 27711\end{array}$}} & $\begin{array}{l}\text { 13. Type of Report \& Period } \\
\text { Covered } \\
\text { Final }\end{array}$ \\
\hline & & & 14. Sponsoring Agency Code \\
\hline
\end{tabular}

15. SUPPLEMENTARY NOTES

16. ABSTRACT (A 200-word or less tactual summary of most significant information. If document includes a significant bibliography or literature survey, mention it here.)

The preparation of a series of reference materials for chemical analysis of natural precipitation is described. The materials consist of ampoules of concentrates which can be diluted to simulate naturally collected samples of rainwater. The analytical measurements made to verify the composition of the samples are also described.

17. KEY WORDS (six to twelve entries; alphabetical order; capitalize only the first letter of the first key word unless a proper name; separated by semicolons) Chemical analysis; rainwater analysis; reference materials.

18. AVAILABILITY - XX Unlimited

For Official Distribution. Do Not Release to N'TIS

Order From Sup. of Doc., U.S. Government Printing Office

Washington, D.C. 20402 , SD Cat. No. C13

CX Order From National Technical Information Service (NTIS) Springfield, Virginia 22151

\begin{tabular}{|l|c|}
\hline $\begin{array}{l}\text { 19. SECURITY CLASS } \\
\text { (THIS REPURT) }\end{array}$ & 21. NO. OF PAGES \\
UNCL ASSIFIED & 23 \\
\hline $\begin{array}{l}\text { 20. SECURITY CL.ASS } \\
\text { (THIS PAGE) } \\
\text { UNCLASSIFIED }\end{array}$ & 22. Price \\
\end{tabular}

USCOMM-DC $29042-P 74$ 



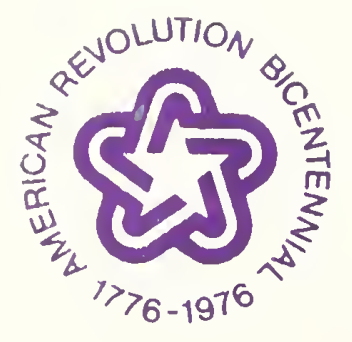

